\title{
Cointegration inferences on issues of poverty and population growth in Nigeria
}

\author{
Inibehe G. Ukpong ${ }^{1 *}$, Ineye D. Ekpebu ${ }^{2}$ and Nneoyi I. Ofem ${ }^{3}$ \\ ${ }^{1}$ School of Agriculture, Policy and Development, University of Reading, Reading RG6 6AR United Kingdom. \\ ${ }^{2}$ School of Agricultural Technology, Federal Polytechnic, Ekowe, P. M. B. 110, Yenagoa, Bayelsa State, Nigeria. \\ ${ }^{3}$ Department of Agricultural Economics and Extension, Faculty of Agriculture, University of Calabar, Nigeria.
}

Accepted 2 July, 2013

\begin{abstract}
Nigeria is the most populated black nation in the world, with enormous wealth from crude petroleum however, the country has been facing numerous socio-economic challenges including poverty. This paper discusses issues of poverty and population growth in Nigeria. The Augmented Dickey-Fuller tests as well as the Engle Granger and Johansen's cointegration tests were used to test for cointegration and stationarity of the time series data on poverty rate, population growth and gross domestic product (GDP) real growth rate in Nigeria, while the ordinary least squares (OLS) regression analysis was used to estimate a statistical model for their relationship. The results show that the variables are trend stationary and cointegrated; with a positive relationship between poverty rate and population growth, and negative relationship between GDP real growth rate and poverty rate in Nigeria. Hence, the need for the government to implement strict policies to reduce the country's population growth, while ensuring increased investment in human capital development, agriculture and technology for greater productivity and poverty reduction.
\end{abstract}

Key words: Cointegration, poverty, population growth, Nigeria.

\section{INTRODUCTION}

Nigeria is the world's most populous black nation with an estimated population of 162 million people (FAO, 2012). It is an agrarian society with about $80 \%$ of its population living in the rural areas; practicing agriculture; as the main source of livelihood (Adeyemo and Zoufa, 2010). The country becomes significant in the world's economic history following its abundant natural resources, ranging from crude petroleum (oil and gas), to rich water resources, massive fertile arable land and rich forest resources (Ekpebu and Ukpong, 2012). Moreover, her fast increasing population makes Nigeria a popular and economically important country of focus to investors; including those from America, China, Europe, and other nations. However, despite these enormous wealth and prominence, Nigeria still remains one of the poorest countries in the world; ranking among the highest in global poverty rankings; with over $70 \%$ of its population said to be living below the poverty line (USAID, 2011).

Population growth remains a critical factor in the development of any economy and where not properly managed, could inflate the scourge of poverty in the economy. On the other hand, population growth can be a useful factor in providing a workforce for the production of goods and services to boost economic development, and remains a critical determinant of the potential of a country's investment. However, increase in population alone may not increase poverty incidence in a country, considering the development in China, and other countries, that have noticed considerable economic growth over the last decades despite their large 
population size. Poverty especially in Africa has been noted to be prevalent in the rural areas, where greater population lives, with poorly developed human resources and poor access to basic necessities of life (IFAD, 2012). Poverty incidence in Nigeria can be seen from the prevalent low life expectancy, high infant mortality, and high death rates, mainly due to poor access to quality and affordable health care services (World Bank, 2010).

Moreover, there is a likelihood of increasing poverty incidence in an economy such as Nigeria that depends almost solely on revenues from crude oil production (Oando, 2009), with declining agricultural productivity, coupled with cases of corruption, income inequality and poor management of resources. The relationship between poverty, population growth and economic growth has attracted scholarly attention (Kohli, 2004; IRP, 2012). There has also been concern over the influence of population growth on unemployment and food security (Etekpe and Inyang, 2008). However, as the population of Nigeria is likely to hit 389.615 million people in 2050 (FAO, 2012), the danger it portrays is likely to worsen the poverty situation. Based on this background, the main objective of this study is to determine the relationship between poverty, gross domestic product (GDP) and population growth in Nigeria, with in-depth discussion on these issues with a view to provide a background that will enhance appropriate policy formulation and economic decisions toward reducing poverty and population growth in the country.

\section{Population and poverty nexus}

Africa remains the world's second largest continent after Asia, with a population which increased from 221 million people in 1950 to 888 million people in 2005 and 1 billion in 2009 (IFAD, 2013; WHES, 2013). The continent has been facing the growing challenge of increased poverty incidence and high population growth, in recent decades, there has been increased cases of political instability, climate change issues, declining agricultural production and terrorism which have worsened the economic status of many countries within the continent, including Somali, Sudan, Congo, Mali and Libya, as well as Nigeria with its most recent threat from terrorists. Poverty in Africa has been of increased global concern with high population of poor people in the continent living in the rural areas and depends almost solely on agriculture (IFAD, 2013).

FAO (2010) recorded that an estimate of 925 million people were hungry worldwide, while Africa is the second largest continent with the highest number of hungry and malnourished people, with 239 million people in SubSaharan Africa classified as hungry and malnourished in 2010. This means that about $25 \%$ of the world's hungry and malnourished people live in Sub-Saharan Africa. IFAD (2013) reported that more than 218 million people in sub-Saharan Africa are said to live in extreme poverty and $70 \%$ of the region's poor people live in the rural areas. Population growth has been identified as one of the principal causes of poverty in most continents including Africa and Asia (WHES, 2012). In other words, rapid increase in Africa's population since 1950 along with other negative factors including conflict and environmental problems have resulted to limited growth in per capita income causing poverty and hunger in Africa, and Asia where most of the poor rural households tend to have larger family sizes (IFAD, 2013).

Population imposes a challenge on a country in terms of economic planning, by influencing the demand magnitude of the people for basic necessities of life, for instance, if a country's population grows rapidly, there is a tendency that the country's demand for food, infrastructure, shelter, employment and other basic needs of life, would increase concurrently, hence, rapid population growth can be seen as a challenge on economic growth especially where there is insufficient resources (WHES, 2012).

As Africa's most populous nation, Nigeria remains the most populated black nation in the world with enviable wealth from crude petroleum, providing a great market and investment potentials for different economic activities, which can be harnessed by other economies of the world. However, the country faces numerous socioeconomic problems including; poverty, corruption, hunger and social unrests, alongside continuously increasing population growth. In other words, Nigeria records increasing poverty incidence in the midst of enormous natural endowments (Cozay, 2011).

Nigeria's socio-economic problems span across all regions within the country. Particularly, the northern region has been noted to have high prevalence of poverty, which is presumed to be the root cause of unrest and social upheavals. Moreover, the region records the highest population of about 75 million people against about 65 million people in the south, as at 2006, and has experienced increased poverty incidence averaged at $35.17 \%$ in 1980 and $70.13 \%$ in 2004 , while the southern region recorded an average poverty incidence of $13.17 \%$ in 1980, and 34.93 in 2004 (Omonona, 2010). Apart from evidences of corruption and other economic inadequacies, high poverty incidence in northern Nigeria cannot be separated from the influence of high population growth, high rate of illiteracy and poor rural infrastructure. In general, poverty rate in Nigeria has been increasing since the 1980s despite increase in the country's revenues from sales of crude oil. As at 1980, Nigeria's poverty rate was as low as $27.2 \%$, but within the past 30 years increased to $69 \%$ in 2010 (NBS, 2010). Also, annual population increased considerably with time, from 75.5 million people in 1980 to 162.5 million people in 2011 (FAO, 2012), and has been estimated at 233 million by 2020 , and 389.615 million by 2050 (PRB, 2012).

Poverty in Nigeria also encompasses issues of diseases, low quality of life and hunger; of which rural 
population; mainly women and children are most vulnerable, and seem to bear the most pressing burdens of world's poverty, yet, women play significant roles in rural economic development, mainly in agricultural activities (UNWomen, 2011). High population growth has brought about high food demands, triggering tremendous hike in food deficit and high food import bills, for instance, Nigeria's food import bills have been increasing tremendously over the last decades with 991 billion Naira spent on cereals and 97 billion Naira on fish in 2010 (ThisdayLive, 2011). Moreover, with its fast growing population size, Nigeria faces problems of rising urban population and urban encroachment, which also pose constraints to agricultural production and human livelihoods (Sule, 2004).

Nigeria has a multi-dimensional poverty index of 0.368 , and predominant evidence of inequality, with inequalityadjusted human development index value of 0.246 , while, intensity of social exclusion and deprivation from basic necessities was estimated at $57.9 \%$, with about $8 \%$ prevalence of undernourished in total population between 2009 and 2010 (UNDP, 2010; Aigbokhan, 2008), besides, the country is ranked fourth with highest number of underweight children in the world (UNICEF, 2010).

World bank (2013) recorded that $68 \%$ of Nigerians survived on less than $\$ 1.25$ a day in 2010 . It is also evident that the rural population in Nigeria face higher poverty incidence than those in the urban areas, meanwhile, a greater percentage of Nigeria's population live in the rural areas, predominantly women and children; as most men often migrate to urban cities in search of better livelihood (Omonona, 2010).

Moreover, there has been increased illegal migration within the African continent coupled with increased number of refugees over the years, due to war and poor economic conditions (UNHCR, 2012). In other words, there is a long history of porous borders within African countries, for instance, Nigeria still face the challenge of influx of illegal immigrants from other African countries including Niger, Cameroun, Benin republic and other African countries. Migration within Africa has been as a result of worsening economic and political situation which have engulfed the continent over the years (Adepoju, 2000). These illegal immigrants also compete with the people for food, infrastructure and other basic means of livelihoods. Meanwhile, Nigeria which has been ranked $7^{\text {th }}$ with an estimated 170 million people in 2012, is expected to rank $4^{\text {th }}$ behind the United States $\left(3^{\text {rd }}\right)$, China $\left(2^{\text {nd }}\right)$ and India $\left(1^{\text {st }}\right)$, as one of the world's most populated nations by 2050 with a projected population of 402 million people, whereas, China which is the most populous nation in the world today with an estimated population of 1.35 billion people, above India with 1.26 billion, is expected to be the $2^{\text {nd }}$ most populated nation in the world by 2050 with a decrease in population projected at 1.313 billion behind India with an increased population of 1.692 billion people by 2050 (PRB, 2012). The decrease in China's population has been due to strict population control laws.

Nevertheless, population growth would be of great advantage to a country's economic growth if such human resources are engaged efficiently in technological advancement and agricultural development. Unfortunately, the large population live in the rural areas where the people lack access to basic infrastructure, or in countries facing severe environmental problems such as drought, flood and other climate change difficulties making economic activities, mainly agricultural production non-sustaining resulting to food shortage, hunger and poverty (IFAD, 2013). It is therefore important that in the quest to achieve poverty reduction and sustained economic growth in the world, rural poverty in particular should be targeted through adequate measures to improve rural infrastructure and ensure agricultural development to enhance increased food production and increased income for the people.

Therefore, Nigeria and countries facing the composite challenges of poverty and population growth should enforce proper immigration and birth control laws, and implement proper documentation of births. In addition, women should also have the right to be part of the decision on family size, as most households sometimes impose on the women the burden of giving birth to large number of children. More so, individuals should be encouraged through intense orientation programmes to show commitment towards population reduction with compliance to government policies and economic reforms.

\section{MATERIALS AND METHODS}

Data used for this study are mainly secondary, and include time series data on Nigeria's annual poverty rate, population growth and GDP real growth rate between 1980 and 2011. Data on population growth in Nigeria were adapted from the food and agriculture organization of the United Nations (FAO, 2012), while data on poverty rate in Nigeria were sourced from the national bureau of statistics (NBS), Nigeria, and figures for GDP real growth rate were adapted from the international monetary fund (IMF, 2011) and the world fact book of the central intelligence agency (CIA, 2012). The statistical package for social sciences (SPSS) was used to carry out the ordinary least squares (OLS) linear regression to estimate a model for the relationship between poverty rate, population growth and GDP real growth rate, while the easy regression statistical package, EasyReg-2011 version (Bierens, 2011) was used to carry out tests for unit root, cointegration and stationarity of the time series. The augmented dickey fuller (ADF) tests; I, II and III were used to test for unit root and stationarity of the series, while the Engle-Granger and Johansen's cointegration procedures were used to further test for cointegration and stationarity of the series. The Johansen's cointegration with no cointegrating restrictions imposed on the intercept parameters was used based on the vector error correction model (VECM) test equation as specified in (Bierens, 2011),

$Y(t)-Y(t-1)=A(1)(Y(t-1)-Y(t-2))+\ldots+A(p)(Y(t-p+1)-Y(t-p))+a \cdot b^{\prime} Y(t-p)+c+U(t)$

Where, $Y(t)$ is a 3-vector with components: $Y(1, t)=\operatorname{Povr}_{(t)} ; Y(2, t)=$ $\operatorname{Popg}_{(t)} ; Y(3, t)=\operatorname{Gdpr}_{(t)}, b^{\prime} Y(t-p)=e(t-p)$, say, is the r-vector of error correction terms, with $b$ the $3 x r$ matrix of cointegrating vectors, $c$ is 
Table 1. Tests for unit root and stationarity using augmented dickey fuller (ADF) tests.

\begin{tabular}{|c|c|c|c|c|c|c|}
\hline \multirow{2}{*}{ Variable } & \multirow{2}{*}{ p-value } & \multirow{2}{*}{ t-value } & \multirow{2}{*}{ R-square } & \multicolumn{2}{|c|}{ Asymptotic critical regions } & \multirow{2}{*}{ Conclusion } \\
\hline & & & & $5 \%$ & $10 \%$ & \\
\hline \multicolumn{7}{|c|}{ ADF I TEST } \\
\hline $\operatorname{Povr}_{(t)}$ & 0.8600 & 0.6865 & -0.0012 & -1.93 & -1.60 & Not rejected \\
\hline $\operatorname{Popg}_{(t)}$ & 0.9400 & 1.2240 & 0.9999 & -1.93 & -1.60 & Not rejected \\
\hline $\operatorname{Gdpr}_{(\mathrm{t})}$ & 0.3400 & -0.8457 & 0.3197 & -1.93 & -1.60 & Not rejected \\
\hline \multicolumn{7}{|c|}{ ADF II TEST } \\
\hline $\operatorname{Povr}_{(t)}$ & 0.5500 & -1.4644 & 0.1024 & -2.89 & -2.58 & Not rejected \\
\hline $\operatorname{Popg}_{(\mathrm{t})}$ & 1.0000 & 1.2132 & 0.9999 & -2.89 & -2.58 & Not rejected \\
\hline $\operatorname{Gdpr}_{(\mathrm{t})}$ & 0.4400 & -1.6658 & 0.37868 & -2.89 & -2.58 & Not rejected \\
\hline \multicolumn{7}{|c|}{ ADF III TEST } \\
\hline $\operatorname{Povr}_{(t)}$ & 0.1600 & -2.9352 & 0.2950 & -3.40 & -3.13 & Not rejected \\
\hline $\operatorname{Popg}_{(t)}$ & 1.0000 & 0.5760 & 0.9999 & -3.40 & -3.13 & Not rejected \\
\hline $\operatorname{Gdpr}_{(\mathrm{t})}$ & 0.3200 & -2.5136 & 0.4591 & -3.40 & -3.13 & Not rejected \\
\hline
\end{tabular}

Abbreviations: $\operatorname{Povr}_{(t)}$, poverty rate; $\operatorname{Popg}_{(t)}$, population growth; $\operatorname{Gdpr}_{(t)}$, gross domestic product (GDP) real growth rate; Source: Computed from data adapted from NBS, 2012; FAO, 2012; IMF, 2011; CIA, 2012.

a3-vector of constants, and $\mathrm{U}(\mathrm{t})$ is the 3 -vector of error terms, a and $\mathrm{A}($.$) 's are conformable parameter matrices, and \mathrm{t}=1(=1979)+$ $\mathrm{p}, \ldots, 32(=2011)$.

The essence of the cointegration analysis was to confirm that the variables were stationary and related; such that a change in one variable would lead to a change in the other, hence, a regression model describing the relationship between variables, say $y_{t}$ and $x_{t}$ will not be spurious, therefore, suitable for describing the relationship between the variables. In other words, if the variables $y_{t}$ and $x_{t}$ are cointegrated hence; a change in policy leading to a change in one variable, say $x_{t}$ will also result to a change in the other variable, say $y_{t}$. The estimated OLS linear regression function as described by Hills et al. (2008) was used to determine the relationship between the variables, such that;

$E\left(y_{i}\right)=\beta_{1}+\beta_{2} X_{2}+\beta_{3} X_{3} \ldots+\beta_{n} X_{n}$

Where; $y_{i}$ is the dependent variable; $X_{2}, X_{3}, X_{n}$ are explanatory variables, while $\beta_{1}$ is the intercept and $\beta_{2}, \beta_{3}, \beta_{n}$; are coefficients of $\mathrm{X}_{2}, \mathrm{X}_{3}, \mathrm{X}_{\mathrm{n}}$ to be determined.

The GDP real growth rate was used to capture the impact of economic growth on poverty rate alongside annual population growth in Nigeria.

\section{RESULTS AND DISCUSSION}

\section{Tests for unit root and stationarity}

The ADF I test was used to test for unit root against the alternative hypothesis that there are zero mean stationarity among the variables. The results in Table 1 show that the null hypothesis was not rejected at 5 and $10 \%$ levels of significance, indicating presence of unit root in the series, hence, the series are non-stationary. The result of the ADF II test which tests the null hypothesis that the series is a unit root process against the alternative hypothesis that the series is stationary around a constant, also shows that the null hypothesis was not rejected at 5 and $10 \%$ levels of significance, indicating that the series, poverty rate, population growth and GDP real growth rate are unit root processes and non-stationary around a constant.

The ADF III tests which test the null hypothesis that the series are unit roots with drift against the alternative hypothesis that they are linear trend stationary also show that the null hypothesis was not rejected at 5 and $10 \%$ levels of significance indicating that the series are unit roots with drift, hence not linear trend stationary. However, although the ADF tests results show that the series are unit root processes and nonstationary, it was necessary to carry out further tests for cointegration and stationarity of the series using the Engle-Granger and Johansen's procedures.

\section{The Engle-Granger cointegration procedures}

The Engle-Granger allows for the OLS residuals to be tested for unit root and stationarity. The result in Table 2 shows that the null hypothesis that the series is a unit root was rejected which implies that the OLS residual of poverty rate is not a unit root, hence, stationary. As discussed above, the result means that the time series of poverty rate, population growth and GDP real growth rate are stationary and cointegrated. To further confirm the result of the Engle-Granger procedures, the Johansen's cointegration analysis was also applied, which was important since the Johansen's procedures allow for more than one cointegrating relationship (Bierens, 2012). 
Table 2. Unit root test on ordinary least squares (OLS) residuals.

\begin{tabular}{lccccc}
\hline Variable & p-value & $\mathbf{t}$-value & R-Square & Critical region (5\% Significance level) & Conclusion \\
\hline OLS residual of poverty & 0.0100 & -2.5116 & 0.2941 & -1.93 & Rejected \\
\hline
\end{tabular}

Abbreviation: OLS, Ordinary least squares

Table 3. Summary of the Johansen's cointegration Test.

\begin{tabular}{|c|c|c|c|c|c|c|c|}
\hline \multirow{2}{*}{$\mathbf{r}$} & \multirow{2}{*}{ Test statistics } & \multicolumn{3}{|c|}{ Critical regions } & \multicolumn{3}{|c|}{ Conclusion } \\
\hline & & $20 \%$ & $10 \%$ & $5 \%$ & $20 \%$ & $10 \%$ & $5 \%$ \\
\hline \multicolumn{8}{|c|}{ Lambda-max test } \\
\hline 0 & 132.8 & 16.3 & 18.7 & 20.8 & Rejected & Rejected & Rejected \\
\hline 1 & 21.5 & 10.1 & 12.1 & 14.0 & Rejected & Rejected & Rejected \\
\hline 2 & 7.2 & 1.7 & 2.8 & 4.0 & Rejected & Rejected & Rejected \\
\hline \multicolumn{8}{|c|}{ Trace test } \\
\hline 2 & 7.2 & 1.7 & 2.8 & 4.0 & Rejected & Rejected & Rejected \\
\hline 1 & 28.7 & 11.2 & 13.3 & 15.2 & Rejected & Rejected & Rejected \\
\hline 0 & 161.5 & 23.9 & 26.8 & 29.5 & Rejected & Rejected & Rejected \\
\hline
\end{tabular}

Conclusion: $r=3$ (This means that $Y_{(t)}$ is (trend) stationary); $Y_{(t)}$ is a 3-vector with components; $\operatorname{Povr}_{(t)}, \operatorname{Popg}_{(t)}$ and $G_{d p r}(t)$.

\section{Johansen's cointegration test}

Table 3 shows a combination of the Lambda Max and Trace tests from the Johansen's cointegration analysis. The Lambda Max test was used to test the null hypothesis that there are $r$ cointegrated vectors against the alternative that there are $r+1$ cointegrated vectors; while the Trace test was used to test the null hypothesis that there are at most $r$ cointegrated vectors against the alternative that there are 3 cointegrated vectors. The overall results show that the null hypotheses were rejected at 20, 10 and 5\% significance levels; which indicate that $Y_{(t)}$ is (trend) stationary. Recall that $Y_{(t)}$ is a 3vector with components; $\operatorname{Povr}_{(t)}, \operatorname{Popg}_{(t)}$ and $\operatorname{Gdpr}_{(t)}$ (Equation 1). This also confirms that the variables, poverty rate, population growth and GDP real growth rate are stationary and cointegrated, hence, it is appropriate to make inferences from the OLS linear regression model describing the relationship between the variables.

\section{OLS linear regression analysis}

The overall model summary and ANOVA result in Table 4 shows the R-square for the regression as $0.71(71 \%)$ with a significant $p$-value of 0.000 ; confirming a good model fit. Table 5 shows that the $p$-values for population growth $(0.000)$ and GDP real growth rate (0.027) are significant at $95 \%$ confidence level of significance, confirming that the two independent variables have significant influence on poverty rate in Nigeria within the period 1980 and 2011.

The ordinary least squares regression result for the relationship between poverty rate, population growth and
GDP real growth rate in Nigeria gives the model as,

$\operatorname{Povr}_{(t)}=5.87+0.43 P_{o p g}(t)-0.46 G_{d p r}(t)$

Where, $\operatorname{Povr}_{(t)}=$ poverty rate; $\operatorname{Popg}_{(t)}=$ population growth, and $\mathrm{Gdpr}_{(\mathrm{t})}=\mathrm{GDP}$ real growth rate in Nigeria between 1980 and 2011.

The model shows that there is a positive relationship between population growth and poverty rate in Nigeria, such that an increase in population growth would result to an increase in poverty rate given the trend of economic scenario in the country between 1980 and 2011. This confirms the reports by IFAD (2013) and WHES (2012) that high population growth is a challenge to economic growth, and among the principal causes of poverty in Africa. More so, with a projected population of 389.62 million people by 2050 , the country's poverty rate may be outrageous. However, reduction in population growth alone cannot also reduce poverty in the country unless the reduction is accompanied with improvement in other sectors of the economy that can improve the wellbeing of the people.

The model also shows a negative relationship between poverty rate and GDP real growth rate, indicating that the trend of GDP real growth over the past 32 years have helped in poverty reduction in the country. However, the country's GDP real growth rate increased from $5.39 \%$ in 2005 to $8.72 \%$ in 2010 , yet poverty rate also increased from $60 \%$ in 2005 to $69 \%$ in 2010 (IMF, 2011; CIA, 2012).

This implies that increase in GDP alone cannot always result to reduction in poverty unless such growths are complemented with tangible improvement of economic variables that will improve the livelihoods of the people. This confirms the report by UNDP (2012) that economic 
Table 4. Model summary and ANOVA.

\begin{tabular}{lcccccc}
\hline Model & Sum of square & Df & Mean square & Standard error & R-square & p-value \\
\hline Regression & 3492.82 & 2 & 1746.41 & 7.09 & 0.71 & $0.000^{\mathrm{a}}$ \\
Residual & 1457.53 & 29 & 50.260 & & & \\
Total & 4950.36 & 31 & & & & \\
\hline
\end{tabular}

a. Predictors: Constant, GDP real growth rate, Population growth; b. Dependent Variable: Poverty Rate; Abbreviation: ANOVA: Analysis of Variance; Df: Degree of freedom

Table 5. Summary of ordinary least squares (OLS) regression analysis.

\begin{tabular}{lcccc}
\hline Model & Coefficient & Std. Error & t-stat & p-value \\
\hline Constant & 5.8725 & 5.8313 & 1.0070 & 0.3222 \\
Population growth & 0.4338 & 0.0521 & 8.3199 & $0.0000^{*}$ \\
GDP real growth rate & -0.4594 & 0.1977 & -2.3232 & $0.0273^{*}$ \\
\hline
\end{tabular}

* Significant at $5 \%$ level of significance (95\% confidence level).

growth will not reduce poverty, improve equality and produce jobs unless it is inclusive. Hence, Nigeria must address issues of corruption and reinvest its crude oil revenues into people-oriented projects to be able to achieve sustainable economic leverage for the people. In other words, increase in GDP could be misleading as a measure of poverty and indicator of welfare (Kohli, 2004). Also, IRP (2012) reported that "poverty has risen in Nigeria, with almost 100 million people living on less than a $\$ 1$ a day, despite economic growth. Moreover, further increase in poverty rate had been predicted to continue, after 2010 , when about $69 \%$ of Nigerians were recorded to live in absolute poverty; with a GDP real growth rate of $8.72 \%$, indicating an obvious disconnect between the country's GDP real growth rate and poverty rate (NBS, 2012). Therefore, the government should not only focus on increasing GDP growth, but should also pay attention to poverty reduction through improvement in human capital development, provision of basic rural infrastructure, sustainable agricultural development and advancement in science and technology, as well as, policies that would promote reduction in income inequality among the people.

\section{Conclusion}

One major finding of this study is that increase in population can result to poverty and that increase in GDP of a country can reduce poverty especially when accompanied with improvement in other factors that would improve the wellbeing of the people. Hence, this paper supports the fact that, although poverty has a multi-dimensional measure, and could be attributed to a number of causes, it is obvious that where a country's population continues to increase without efficient investment in human capital development, and adequate development in economic sectors, such as agriculture that would improve the livelihoods of the people, then, any increase in population could result to increase in poverty in the economy. Hence, in the quest for poverty reduction in the developing countries, including Nigeria, there is a need for substantial investment in technology and agriculture to promote food sufficiency; increased income and employment. It is important that suitable policies are made to reduce the country's population growth by controlling family size, especially in the rural areas where poor families raise large number of children. The population should be encouraged to developed useful skills in science and technology to meet the country's need for employment and greater productivity. More so, there is need to develop the industrial sector and promote rural development supported with a functional power sector; while targeting industrial growth and agricultural development to enhance improved wellbeing for the people, especially those of the rural areas. Particularly, policies should be made to stipulate an average family size; especially number of children, and such policies should be made to gain support and collaboration of religious groups, cultural organizations and political institutions in the country. Moreover, Nigeria has great potentials for development, but there is need for concerted effort to tackle corruption, income inequality and poor resource management in the country to enhance poverty reduction and economic recovery.

\section{REFERENCES}

Adepoju A (2000). Issues and recent trends in international migration in sub-Saharan Africa. Int. Soc. Sci. J. 52(165):383-394.

Adeyemo AO, Zuofa K (2010). 'Food Security in Bayelsa State: The Challenges.', Programme and Book of Abstracts for the 45th Annual 
Conference of the Science Association of Nigeria, Niger Delta University, Bayelsa State, Nigeria. May, 23-27.

Aigbokhan BE (2008). Growth, Inequality and Poverty in Nigeria, ACGS/MPAMS Discussion Paper, 3. February, United Nations Economic Commission for Africa.

Bierens HJ (2011). EasyReg International.Pennsylvania State University. HYPERLINK "http://econ.la.psu.edu" http://econ.la.psu.edu . June, 17.

Bierens HJ (2012). Spurious Regression. Pennsylvania State University. http://econ.la.psu.edu

CIA (2012). World Fact Book:Nigeria GDP-real Growth Rate, Central intelligence Agency of the United States, viewed 26 July 2012, $<$ http://www.indexmundi.com>.

Cozay (2011). Poverty and Hunger in Nigeria: Major Problems facing Nigeria Today. Cozay African Group, viewed 02 July 2011, < HYPERLINK "http://www.cozay.com" http://www.cozay.com >.

Ekpebu ID, Ukpong IG (2012). Rethinking Agricultural development in Nigeria: Paradox of oil wealth. Author house publishing, Bloomington, United States of America.

Etekpe A, Inyang EU (2008). Political and Economic dimensions of unemployment and job creation in Nigeria. Harey publications coy, Port Harcourt, Nigeria.

FAO (2010). Africa Hunger and Poverty Facts. United Nations Food and Agriculture Organization,<http://www.worldhunger.org>

FAO (2012).Historical and Projected Population of Nigeria. United Nations Food and Agriculture Organization, <http://www.fao.org>

Hills RC, Griffiths WE, Lim GC (2008). Principles of Econometrics (3 $3^{\text {rd }}$ Edition). R. R. Donneylley, USA.

IFAD (2012). Rural Poverty in Nigeria, viewed 10 October 2012, $<$ HYPERLINK "http://www.ruralpovertyportal.org" http://www.ruralpovertyportal.org>.

IFAD (2013). Rural Poverty in Africa. http://www.ruralpovertyportal.org>. IMF (2011). Nigeria GDP-real Growth Rate. 2011 World Economic Outlook.International Monetary Fund.viewed 08 August 2012, $<$ http://www.indexmundi.com>.

IRP (2012). Poverty Rate-Nigeria: Institute for Research on Poverty. University of Wisconsin. HYPERLINK "http://www.irp.wisc.edu" www.irp.wisc.edu .

Kohli U (2004). Real GDP, real domestic Income, and term-of-trade Changes. J. Int. Econ. 62(1):83-106.

NBS (2010). Harmonized Nigeria Living Standard Survey, Nigerian Poverty Profile Report, 2010. National Bureau of Statistics, Nigeria, viewed 12 June 2011, <http://www.proshareng.com>.

NBS (2012). Poverty Profile Report. National Bureau of Statistics, Nigeria. Accesses online on http:/www.punching.com.
Oando (2009). 2008 Annual Report, Oando PLC, Nigeria. July, 2009

Omonona BT (2010). Quantitative Analysis of Rural Poverty in Nigeria. International Food Policy Research Institute, viewed 04 June 2011,< HYPERLINK "http://www.ifpri.org"http://www.ifpri.org >.

PRB (2012).World Population Data Sheet. Population Reference Bureau, <http://www.prb.org>

Sule RO (2004). The Environmental consequences of rapid urbanization in countries of the developing world. Thumbprints Int. Company, Calabar, Nigeria.

ThisdayLive (2011). Nigeria Spends N991 on Rice, Wheat Importation. 15 August, 2011, viewed 08 October 2012 $<$ http://www.thisdaylive.com>.

UNDP (2010). International Human Development Indicators, viewed 3 April 2011, <http://www.hdrstats.undp.org>.

UNDP (2012). Poverty Reduction.The United Nations Development Programme. HYPERLINK "http://www.undp.org" http://www.undp.org

UNHCR (2012). Global Trends Report 2011. United Nations High Commissioner for Refugees. http://www.unhcr.org

UNICEF (2010). Providing Relief for Malnourished Children in Nigeria, viewed 10 October 2012, < HYPERLINK "http://www..unicef.org" http://www.unicef.org >.

UNWomen (2011). Women, Poverty and Economics. Entity for Gender Equality and the Empowerment of Women, viewed 03 April 2011, $<$ http://www.unifem.org $>$.

USAID (2011). Nigeria, viewed 15 July 2011, < HYPERLINK "http://www.usaid.gov" http://www.usaid.gov >.

WHES (2012). World Hunger and Poverty Facts and Statistics. World Hunger Education Services. http://worldhunger.org.

WHES (2013). Africa hunger and poverty facts. World Hunger Education Services. http://worldhunger.org.

World Bank (2010). World Development Indicator Data Base, viewed 23 July 2011, <http://www.ddp-ext.worldbank.org>.

World Bank (2013). Poverty headcount ratio at national poverty line. The World Bank. data. worldbank.org. 